\title{
Eucalyptus camaldulensis Woodlot Influences Soil Properties and Teff Yield on the Adjacent Croplands in Guraghe Zone, Central Ethiopia
}

\author{
Begashaw Mitiku ${ }^{1 *}$, Bekele Lemma ${ }^{2}$, Fantaw Yimer $^{3}$ \\ ${ }^{1}$ Southern Agricultural Research Institute, Werabe Agricultural Research center \\ ${ }^{2}$ Department of Chemistry, Hawassa University \\ ${ }^{3}$ Wondo Genet College of Forestry and Natural Resources, Hawassa University
}

\begin{tabular}{c} 
Article History \\
Received: 29.12 .2021 \\
Accepted: 05.02 .2022 \\
Published: 10.02 .2022 \\
Journal homepage: \\
https://www.easpublisher.com \\
Quick Response Code \\
\hline
\end{tabular}

\begin{abstract}
In Ethiopia five Eucalyptus species were adopt wide area and Eucalyptus camaldulensisi more dominant in low land and middle land area and economically very important. This leads to farmers converted portion of their farmland to Eucalyptus camaldulensis woodlots. The aim of this study was to assess the impact of E. camaldulensis woodlot on the soil properties and teff (Erogrsticteff) yields on an adjacent cropland. A plot of $2 \mathrm{~m} \times 1.5 \mathrm{~m}$ area was laid down inside plantation (assumed zero $\mathrm{m}$ ), at one, three, six, nine and $20 \mathrm{~m}$ distances away from the $\mathrm{E}$. camaldulensis woodlot in to the adjacent cropland. This was replicated on three farmlands. Teff was grown on the plots and the yield, height, and biomass of teff were measured and thirty six soil samples were collected from experimental field. The soil bulk density $(\mathrm{p}<0.01)$, soil moisture $(\mathrm{p}<0.001)$, SOC $(\mathrm{p}<0.05)$, avail $\mathrm{P}(\mathrm{p}<$ $0.01)$ and avail $\mathrm{K}(\mathrm{p}<0.01)$ were significantly varied with distance. The yield and height of teff were significantly $(\mathrm{p}<0.01)$ affected by distance from the woodlot. Moreover, mean soil total $\mathrm{N}$ at three meter, avail $\mathrm{P}$ from one meter to six meter, avail $\mathrm{K}$ after nine meter, yield and biomass of teff up to six meter were reduced. The yield reduction of teff could be attributed to the soil moisture and soil nutrient competition between the Eucalyptus woodlot and teff. In this study we had concluded that E. Camaldulensis wood lot has effect on teff production up to sixmeter distance from the woodlot and adjacent crop were recommended after Six meter.

Keywords: Agroforestry Biomass, distance from tree, E. camaldulensis, soil property, teff, yield.
\end{abstract}

Copyright () 2022 The Author(s): This is an open-access article distributed under the terms of the Creative Commons Attribution 4.0 International License (CC BY-NC 4.0) which permits unrestricted use, distribution, and reproduction in any medium for non-commercial use provided the original author and source are credited.

\section{INTRODUCTION}

Eucalyptus is an exotic tree species that grows as form of plantation forests and woodlots particularly in Ethiopia. The tree was successfully introduced in many countries including Ethiopia, and it was cultivated as an important biomass sources under different environmental conditions (Davidson, 1993). E. globulus plantation stands were established initially around Addis Ababa at the beginning of the 20th century, and then Eucalyptus expanded all over the central plateau in the altitudinal range between 1400 to 3500 meters above sea level (Pohjonen and Pukkala, 1991). Then, E. camaldulensis is one from about five to ten species of Eucalyptus those were introduced to Ethiopia in the late nineties (Friis, 1995). Eucalyptus plantations can play useful environmental roles in natural and plantations forests. They can serve as a source of timber, fiber and essential oils; as ornamental and a shade tree in cities, and as a means to water tables in marshy areas (Leicach et al., 2012). The farmers need the tree for fuelling and construction, and also they get economic benefit from selling the tree. This has motivated the farmers to grow trees more and more on their farms. As a result, the integration of Eucalyptus woodlots and crop production was high in the highlands (Lemenih, 2010).

Eucalyptus has long become an essential part of the agricultural landscape of Ethiopia. Early estimates indicate that about 200,000 ha of Eucalyptus have been planted on farm level plantation in Ethiopia (Davidson, 1993). Nowadays the small holder farmer Eucalyptus plantation has increased to 800, 000 ha (Lemenih and Kassa 2014). Despite the benefits of the tree, some studies claim that the expansion of Eucalyptus on farmlands has negative influence on soil fertility (El-khawas and Shehata, 2005; Forrester et al., 2006). Eucalyptus is a fast-growing tree, and the tree has high nutrients up take capacity (Laclau et al., 2005;

*Corresponding Author: Begashaw Mitiku 
Zhang et al., 2015), which removes nutrients from the site with a harvest. The acidity of the soil increased in Eucalyptus plantations (Aweeto and Moleele, 2005 and Syad et al., 2006). The acidifying effect was demonstrated by comparing Eucalyptus plantations and natural forest (Alber, 2016). On the other hand, trees provide a convenient human habitation, improves soil nutrient, serves as wind break, and enhances the climatic condition of the area as well as providing shade for living organism (Verheij, 2004 cited in Kwaku and Wiafe 2014). Similarly, trees on agricultural fields play several important roles such as improving environmental health and for the wellbeing of mankind. Place et al., (2012) stated that agroforestry creates some environmental benefits such as sustainability of biodiversity, watershed protection and carbon sequestration. Few studies investigated the impact of Eucalyptus woodlots on the productivity of crop on the adjacent agricultural land like maize and (Tilashwork, 2009; Alebachew et al., 2015).

Most studies assessed the impact of Eucalyptus plantations by comparing the soil properties between croplands and Eucalyptus plantations (e.g. Lemma et al., 2006; Duguma et al., 2010). However, few studies attempted to show the effect of Eucalyptus on different crops like maize, wheat and sorghum grown adjacent to the tree stand with increasing distance from it to the cropland (Selamyihun et. al., 2004, 2005; Tilashwork et al., 2013). However, the effect of the tree on crops can be influenced by tree species, crop types, agro ecological zones and soil types. According to these, scientific studies on E. camaldulensis effect on soil and crop yield is limited in the country (Ethiopia) and almost nil in the study area particularly on teff
(Eragrostif teff) and vertisols soil type. In addition, the studies done before are only laboratory based on field experiment like Selamyhun et al., (2004) and in the area with nitosol soil type like Tilashwerk et al., (2013). Therefore, this study is design to fill the gap on effect of E. camaldulensis on teff (Eragrostif teff) at adjacent crop land on field that have clay soil (Heavy vertisols). E. camaldulensis woodlots are established adjacent to croplands in the agro-ecosystems of southern Ethiopia. Particularly in the study area the extent of $E$. camaldulensis is rapidly increased. This setting provides a unique opportunity to test the influence of Eucalyptus woodlot on the adjacent croplands and the crops growing on it. Therefore, the present study assessed the effect of Eucalyptus camaldulensis woodlot on the soils of cropland and on teff (Eragrostistef) productivity in the agro-ecosystem of Gurage Zone, southwestern Ethiopia.

\section{MATERIAL AND METHOD Study site description}

This study was conducted in Edja district, Garage Zone in the Southern Nation and Nationalities and Peoples' Regional State (SNNPRS), Ethiopia. It is located at about $197 \mathrm{~km}$ Southwest of Addis Ababa and $42 \mathrm{~km}$ east of Worksite, the capital of the Garage zone (Fig 1). The study site $\left(8^{\circ} 3^{\prime} 18^{\prime \prime} \mathrm{N}-8^{\circ} 14^{\prime} 42^{\prime \prime} \mathrm{N}\right.$ and $\left.37^{\circ} 49^{\prime} 48^{\prime \prime} \mathrm{E}-38^{\circ} 13^{\prime} 12^{\prime \prime} \mathrm{E}\right)$ ranged between 1895 to 3200 m.a.s.l. The mean annual rainfall of the study area was between $950 \mathrm{~mm}$ to $1100 \mathrm{~mm}$, while the mean annual maximum and mean annual minimum temperature were $27.7^{\circ} \mathrm{C}$ and $6.5^{\circ} \mathrm{C}$, respectively. The soil of the study area was classified as Heavy Vertisols (Eyes, 2016).

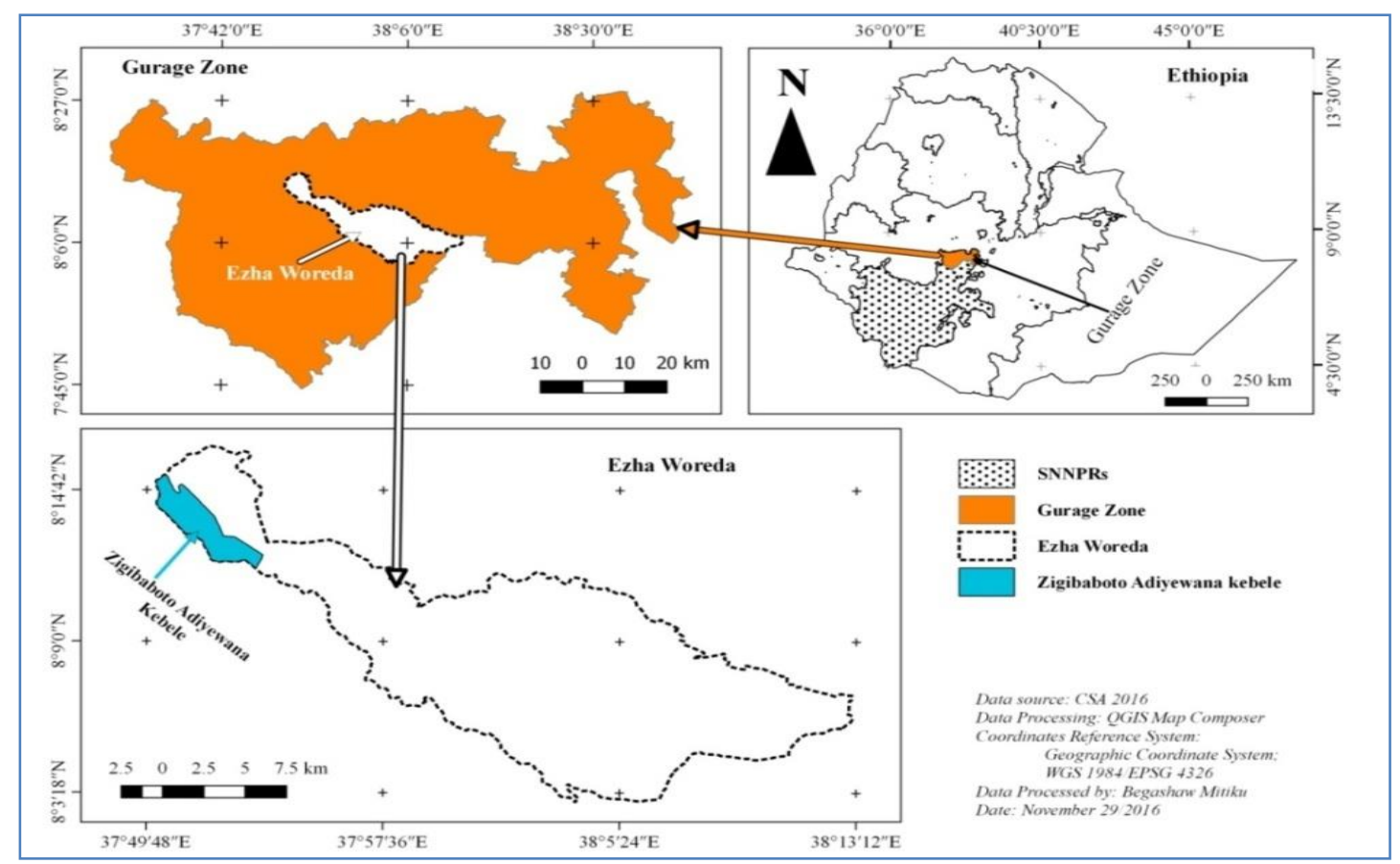

Fig-1: Map of study area 
The major land uses in the study area includes cropland, natural vegetation, grazing land and E.camaldulensis woodlots (hereafter referred simply as Eucalyptus woodlot). The average land holding per household head is less than 0.5 ha, which is one of the main factors exerting a profound influence on land use changes and land use intensification. Enset and cereal based farming systems are the two-major farming system in the area. The common annual food crops in the area are teff (Eragrostif teff), maize (Zea mays L.), finger millet (Panicum miliaceum), and Nug (Guizotia abyssinica) (Ketema, 1997).

\begin{abstract}
Sampling design and soil analysis
Three farmers' holdings with Eucalyptus woodlot and adjacent cropland uses were purposively selected to get woodlots and forms under similar age, management and land use history. Croplands were similar in land management and land use history. Eucalyptus woodlot had nearly similar age of six to seven years; the woodlots were in their fourth rotation, which coppiced after third harvest, and similar management. The DBH and height of Eucalypts woodlot are given below (Table 1).
\end{abstract}

Table-1: Mean ( \pm SD) DBH and height of Eucalyptus in the three smallholder woodlots

\begin{tabular}{|l|l|l|l|l|l|l|}
\hline Sample plots & Average DBH (cm) & \multicolumn{4}{l|}{ Average Height (m) } \\
\hline & W1 & W2 & W3 & W1 & W2 & W3 \\
\hline & $10.6 \pm 0.9$ & $10.6 \pm 1.1$ & $10.4 \pm 1.0$ & $22.9 \pm 1.8$ & $22.5 \pm 1.3$ & $22.7 \pm 1.5$ \\
\hline
\end{tabular}

The design of the present study is Randomized Complete Block Design. Plots of size $2 \mathrm{~m} \times 1.5 \mathrm{~m}$ were laid down at one, three, six, nine and $20 \mathrm{~m}$ distances away from the Eucalyptus woodlot along the adjacent cropland for both soils sampling and sowing of crop (teff). The first distances was fixed starting from the edge of the woodlot and then continue the next distance along the crop land. At the inside of plantation (assumed zero meters) one composite soil sample was taken using diagonal soil sampling methods, which is parallel to the experimental plots. This was replicated on three farmers' holdings.
Accordingly, a total of 18 plots (6 on each farm x 3 replications) were established. Composite soil samples were also collected using core sampler from each plot, the plot fixed parallel to the teff sown plot and free from fertilizer contamination that applied for the crop, at two soil depths (0-10 and 11-30 cm).A total of 36 composite soil samples (6plots x 2 soil depths $\mathrm{x} 3$ replications) were collected for the soil analyses. For bulk density and moisture content determination, separate undisturbed soil samples were collected with a manual core sampler $($ diameter $=5 \mathrm{~cm}$; height $=5 \mathrm{~cm}$ ) from all plots and soil depths.

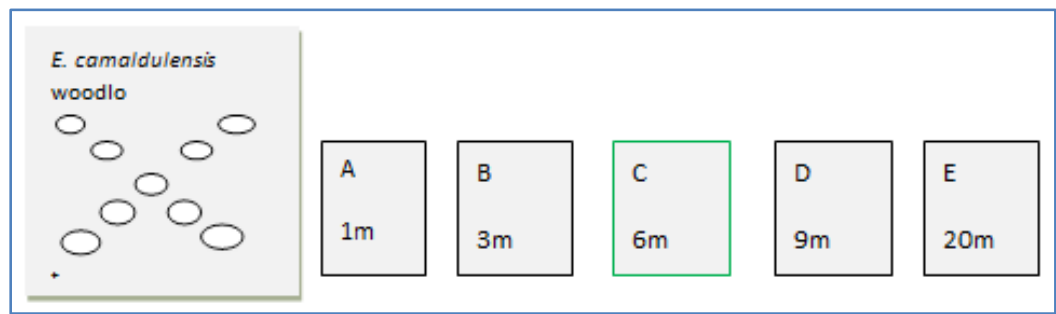

Fig-2: Schematic sketch of plot design in single woodlot; Note: A, B, C, D and E are plots for teff sowing adjacent and circle inside of plantation are pits for soil sampling inside woodlots.

\section{Teff data collection}

An improved variety of teff (cross 37-Tsedey) was used for this study. This teff variety is early maturing and has good grain fillings ability. Teff was sowed at different plots established at each distance (section 2.2.1) and a blanket recommended amount of fertilizer (100 kg/ha DAP and $50 \mathrm{Kg} / \mathrm{ha}$ Urea) was applied each plot equally in plot based amount. In each plot, the height of teff was measured after seed setting, and the above ground biomass and yield of teff were measured after harvest. The effect of Eucalyptus woodlot on height, biomass and yield of teff was determined by comparing among the plots established at different distances. Teff height was measured by using average height of five random teff plants per plot. Teff biomass was determined after harvesting above ground biomass of teff from each plot and drying in sun for two days (48hr).The yield of teff grains was measured by a balance after separating the grains from straw and the moisture of the grain is corrected using $10 \%$ moisture reduction. The yield was expressed as quintal per hectare (qha-1) while the biomass was given t/ha-1.

\section{Soil analysis}

The soil samples were air-dried at room temperature $\left(25^{\circ} \mathrm{C}\right)$, crushed, homogenized, sieved (mesh size $<2 \mathrm{~mm}$ ), and analyzed at the Southern Agriculture and Natural Resource Soil Testing Laboratory, Hawassa, Ethiopia. It was further crushed and sieved (mesh size $<0.5 \mathrm{~mm}$ ) for soil organic $\mathrm{C}$ (SOC) and soil total $\mathrm{N}(\mathrm{TN})$ analyses. The SOC was determined by Walkley and Black method (Walkley and Black 1934).Total $\mathrm{N}$ concentration was determined 
by the Kjeldahl method (Jackson, 1958). The avail $\mathrm{P}$ concentration of the soil was analyzed by Olsen method (Olsen et al., 1954). Available K concentration of soil extract was determined by using flame photometer (Jackson, 1958). The soil $\mathrm{pH}$ was measured using $\mathrm{pH}$ meter in 1:2.5 ratios (soils: water solution). Soil moisture content was determined by gravimetric method after oven drying to a constant weight at $105^{\circ} \mathrm{C}$ for $24 \mathrm{hrs}$ (Anderson and Ingram, 1993). Bulk density was determined after oven drying the undisturbed soil sample at temperature of $105^{\circ} \mathrm{C}$ for 24 hours and then by dividing the oven-dried weight of the sample by its volume.

\section{STATISTICAL ANALYSIS}

Bulk density, moisture content, $\mathrm{pH}, \mathrm{SOC}, \mathrm{TN}$, avail $\mathrm{P}$, and avail $\mathrm{K}$ of soil data and the yield, biomass and height of teff data were analyzed using two-and one-way analysis of variance (ANOVA), respectively, with SPSS statistical software (version 16). Significant results were followed by mean separation using Turkey's test $(\mathrm{p}<0.05)$.

\section{RESULTS AND DISCUSSION \\ Results}

The effect of Eucalyptus woodlot on bulk density, soil moisture and pH

Bulk density showed a significant difference with distance $(\mathrm{p}<0.01)$ from the Eucalyptus woodlot and with soil depth. Bulk density inside and near the Eucalyptus woodlot was significantly lower and increased with increasing distance (Table 2). The soil moisture content showed significant difference with distance from the Eucalyptus woodlot $(\mathrm{p}<0.001)$ and with soil depth $(\mathrm{p}<0.01)$. The moisture contents near the woodlot were significantly lower than the moisture contents away from the woodlot (Table 2). The $\mathrm{pH}$ did not significantly vary $(\mathrm{p}>0.05)$ with distances from woodlot and soil depth (Table 2) indicating the similarity of soil reaction with the cropland.

Table-2: Means ( $($ SD) values of bulk density, moisture content, pH and soil organic carbon (SOC) at 0-10 and 11$30 \mathrm{~cm}$ soil depths with distance from Eucalyptus woodlot

\begin{tabular}{|l|l|l|l|l|l|}
\hline $\begin{array}{l}\text { distance from } \\
\text { E. camaldulensis woodlot }\end{array}$ & $\begin{array}{l}\text { Depth } \\
(\mathbf{c m})\end{array}$ & $\begin{array}{l}\text { bulk density } \\
(\mathbf{g c m}-3)\end{array}$ & $\begin{array}{l}\text { Soil moisture } \\
(\mathbf{\%})\end{array}$ & $\mathbf{p H}(\mathbf{H} 2 \mathrm{O})$ & $\begin{array}{l}\text { SOC } \\
(\mathbf{g} / \mathbf{k g})\end{array}$ \\
\hline Inside woodlot & $0-10$ & $1.04 \pm 0.08 \mathrm{c}$ & $12.5 \pm 2.1 \mathrm{~b}$ & $5.4 \pm 0.1 \mathrm{a}$ & $14.6 \pm 2.6 \mathrm{~b}$ \\
\hline \multirow{3}{*}{ One meter distance } & $11-30$ & $0.99 \pm 0.08 \mathrm{C}$ & $13.7 \pm 1.2 \mathrm{~B}$ & $5.6 \pm 0.1 \mathrm{~A}$ & $13 \pm 2.6 \mathrm{~A}$ \\
\hline \multirow{2}{*}{ three meter distance } & $0-10$ & $1.08 \pm 0.05 \mathrm{c}$ & $12.1 \pm 0.6 \mathrm{~b}$ & $5.5 \pm 0.1 \mathrm{a}$ & $21.0 \pm 7.0 \mathrm{a}$ \\
\cline { 2 - 6 } & $11-30$ & $1.06 \pm 0.10 \mathrm{~B}$ & $14.4 \pm 1.1 \mathrm{~B}$ & $5.6 \pm 0.0 \mathrm{~A}$ & $11.5 \pm 3.6 \mathrm{~A}$ \\
\hline \multirow{2}{*}{ Six meter distance } & $0-10$ & $1.15 \pm 0.02 \mathrm{bc}$ & $12.5 \pm 1.1 \mathrm{~b}$ & $5.6 \pm 0.2 \mathrm{a}$ & $15.0 \pm 3.5 \mathrm{~b}$ \\
\cline { 2 - 6 } & $11-30$ & $1.08 \pm 0.08 \mathrm{~B}$ & $14.5 \pm 0.5 \mathrm{~B}$ & $5.6 \pm 0.1 \mathrm{~A}$ & $9.9 \pm 1.9 \mathrm{~B}$ \\
\hline \multirow{2}{*}{ Nine meter distance } & $0-10$ & $1.18 \pm 0.02 \mathrm{ba}$ & $12.7 \pm 1.8 \mathrm{~b}$ & $5.4 \pm 0.8 \mathrm{a}$ & $17.1 \pm 3.0 \mathrm{ab}$ \\
\cline { 2 - 6 } & $11-30$ & $1.14 \pm 0.11 \mathrm{~B}$ & $13.6 \pm 0.9 \mathrm{~B}$ & $5.5 \pm 0.1 \mathrm{~A}$ & $8.6 \pm 0.2 \mathrm{~B}$ \\
\hline Twenty meter distance & $0-10$ & $1.22 \pm 0.03 \mathrm{a}$ & $15.3 \pm 1.2 \mathrm{a}$ & $5.5 \pm 0.1 \mathrm{a}$ & $16.8 \pm 2.3 \mathrm{~b}$ \\
\cline { 2 - 6 } & $11-30$ & $1.28 \pm 0.0 \mathrm{~A}$ & $15.4 \pm 1.1 \mathrm{~A}$ & $5.6 \pm 0.1 \mathrm{~A}$ & $10.3 \pm 2.1 \mathrm{AB}$ \\
\hline
\end{tabular}

Note: Mean values with distances from the woodlot for the same soil depth followed by the same small letter are not significantly different.

\section{The effect of Eucalyptus woodlot on SOC}

Soil OC was significantly high $(\mathrm{p}<0.05)$ at one meter distance as compared with the rest of the distances zero, three, six, nine and twenty meters from the woodlot (Table 2). However, with exception of SOC at one meter distance, mean SOC showed slightly increasing trend towards the cropland with increasing distance.

\section{The effect of Eucalyptus woodlot on soil nutrients (TN, avail $P$ and avail $K$ )}

Soil TN did not show significant difference with distance from Eucalyptus woodlot, but soil TN is relatively higher at one meter and relatively lower at zero meter distances. Soil TN was higher at the surface soil layer $(0-10 \mathrm{~cm})$ than sub surface soil layer $(10-30$ $\mathrm{cm}$; Figure 2). The concentration of avail Pin the soil significantly differed $(\mathrm{P}<0.01)$ with distance from Eucalyptus woodlot, but not with soil depth (Figure 3).The lowest mean concentration of avail $P$ was recorded at six-meter distance. Avail $\mathrm{P}$ showed a declining trend with distance up to six-meter, and then increasing to nine-meter and remained similar up to twenty meter(Fig. 3). The avail $\mathrm{K}$ concentration in the soil was significantly different $(\mathrm{P}<0.01)$ with distance from the Eucalyptus woodlot and with soil depth. The lowest avail $\mathrm{K}$ concentration was found at nine-meter distance from the woodlot. Available mean $\mathrm{K}$ concentration in the soil showed a declining trend with distance up to nine-meters and increased thereafter from the woodlot (Fig 4). 


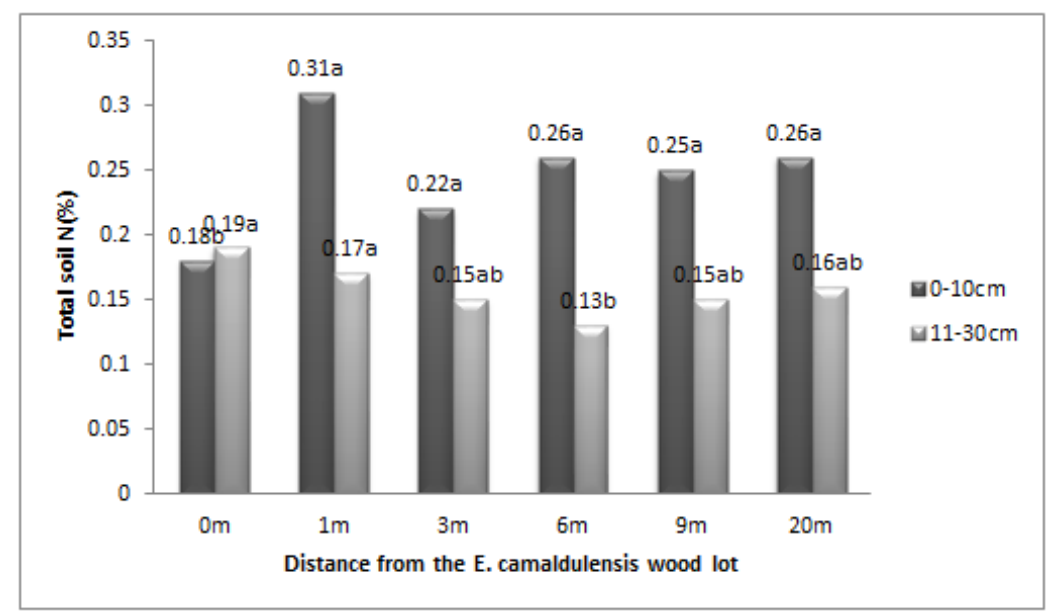

Fig-3: Total nitrogen in percent $(\%)$ at different distance from the $E$. camaldulensis stand and open area at $p$ valu=0.05.

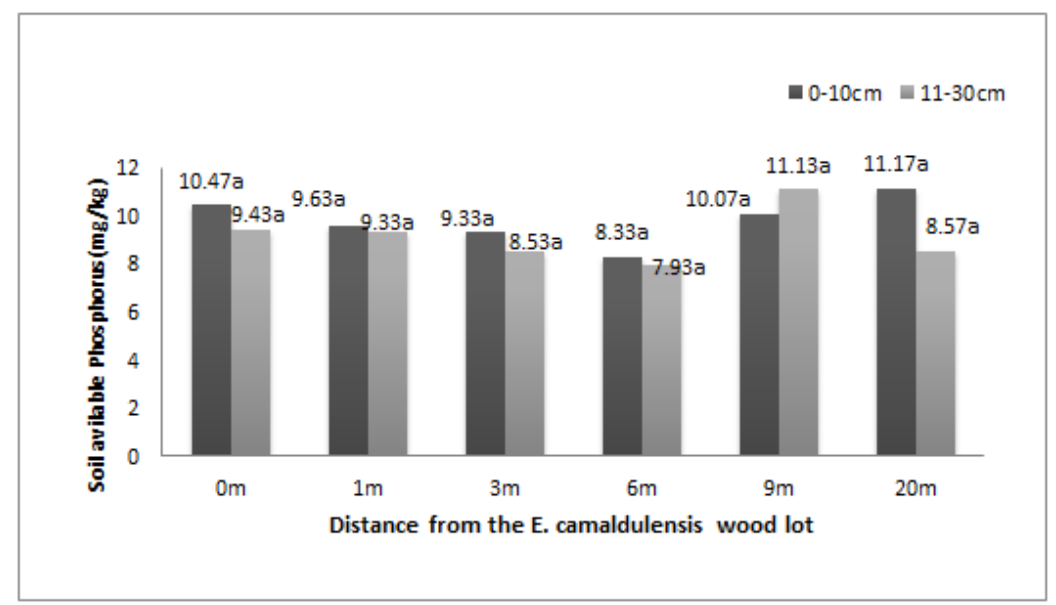

Fig-4: The effect of Eucalyptus Camaldulensis stand on available $P$ at different distance from the stand (at $\mathbf{p}$ valu=0.05).

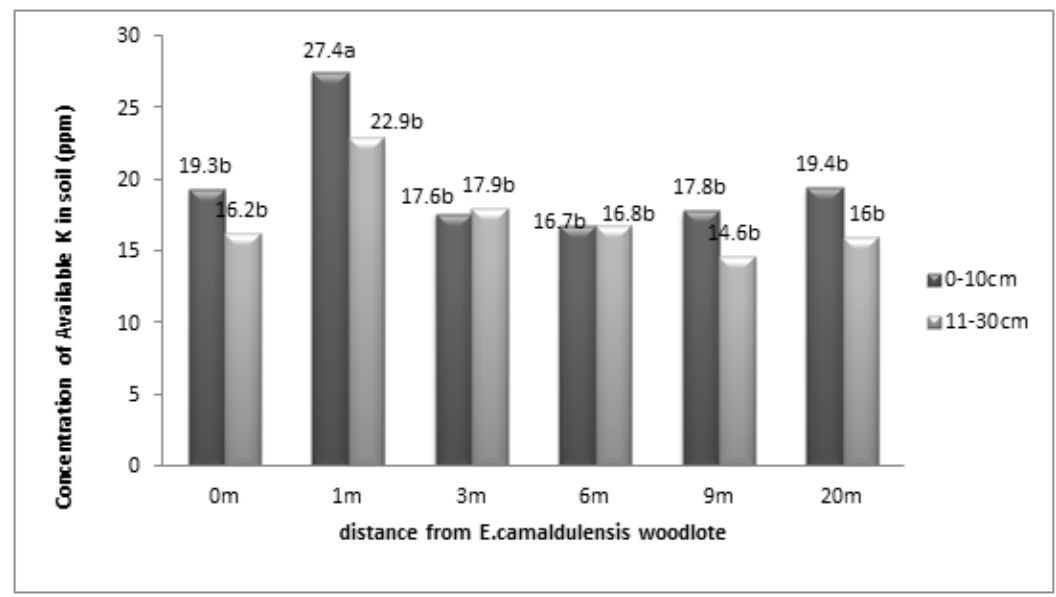

Fig-5: The effect of Eucalyptus Camaldulensis stand on avail $\mathrm{K}$ at different distance from the trunk at $p$ valu=0.05.

The relationship between physico-chemical properties of soil and distance from the stand

The present study shows that some of soil properties under this study were significantly affected by the distance from the E. camaldulensis stand to far apart. Their regression graph also shows that physical properties of soil like soil moisture and bulk density are have highly relation with distance from the $E$. camaldulensis stand. The bulk density of soil decrease with increase of distance but, soil moisture is increase with increase of distance from the Eucalyptus stand. On the other hand from the chemical properties of soil shows that weak relation with distance from the Eucalyptus tree stand. 

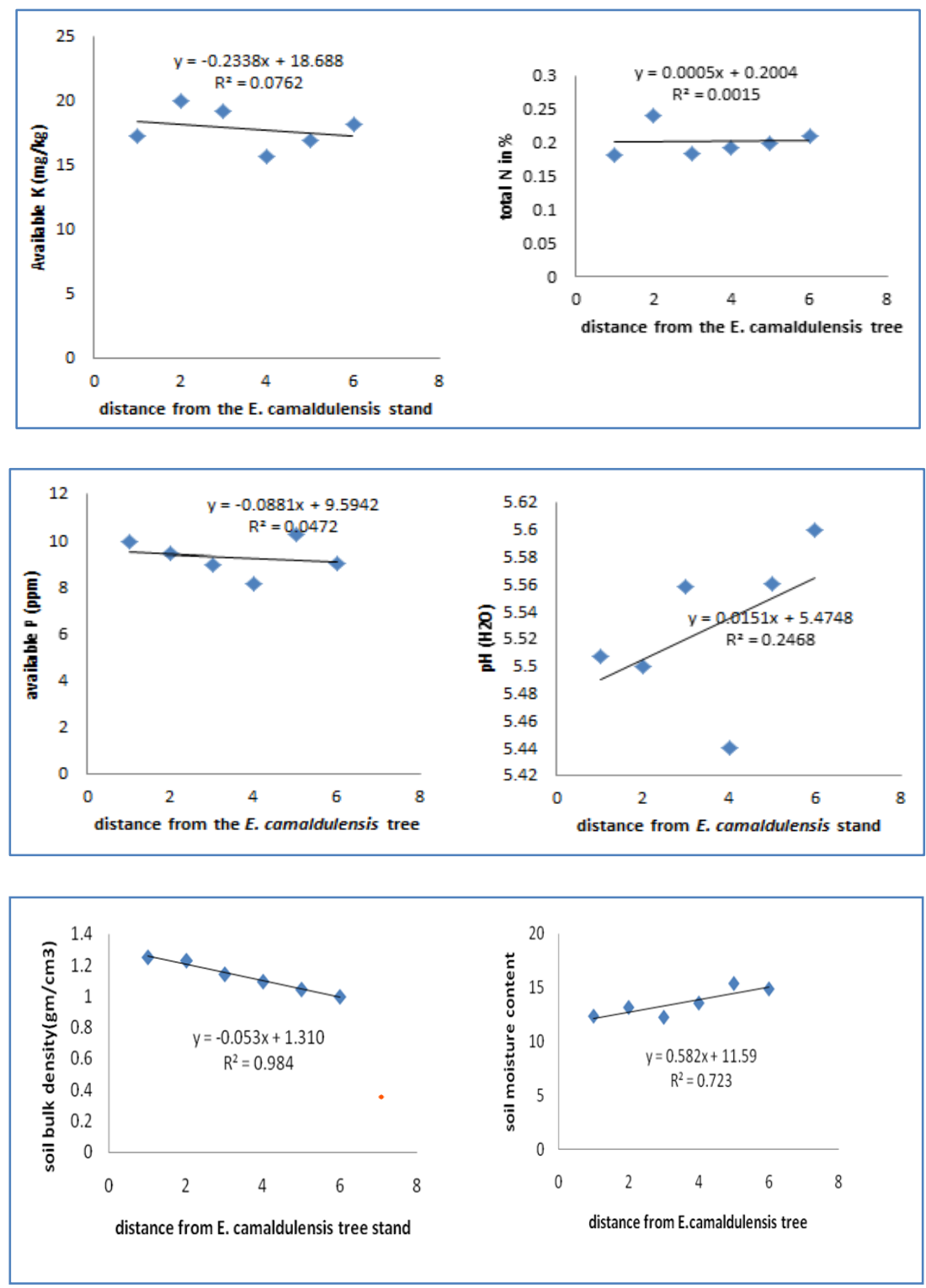

Fig-6: The relationship b/n soil physical and chemical parameters with distance from the woodlot distances (m)

The effect of $E$. camaldulensis woodlot on teff yield planted on the adjacent cropland

Grain yield of teff (Eragrostif teff) was significantly varied $(\mathrm{P}<0.01)$ with distance from Eucalyptus stand (Table2). The highest grain yield was $12.8 \mathrm{qha}^{-1}$ and the lowest $9.2 \mathrm{qha}^{-1}$ at $20 \mathrm{~m}$ and $1 \mathrm{~m}$ distance from Eucalyptus woodlot, respectively. The yield of teff at one, three and six meter distances from Eucalyptus stand showed significant difference $(\mathrm{P}<0.01)$ from twenty meter distance. Biomass of teff was not significantly different at different distances from the woodlot (Table 5). Mean biomass showed an increasing trend with distance from the woodlots.

Table-3: Mean ( \pm SE) values of yield and biomass of teff with distance from E.camaldulensis

\begin{tabular}{|l|l|l|}
\hline $\begin{array}{l}\text { Distance from } \\
\text { E. camaldulensis woodlot }\end{array}$ & $\begin{array}{l}\text { Yield } \\
(\mathbf{q} / \mathbf{h a})\end{array}$ & $\begin{array}{l}\text { Biomass } \\
\text { (t/ha) }\end{array}$ \\
\hline One meter distance & $9.2 \pm 1.7 \mathrm{~b}$ & $7.4 \pm 0.8 \mathrm{a}$ \\
\hline Three meter distance & $9.8 \pm 1.4 \mathrm{~b}$ & $9.1 \pm 2.1 \mathrm{a}$ \\
\hline Six meter distance & $10.8 \pm 2.1 \mathrm{ab}$ & $9.5 \pm 2.0 \mathrm{a}$ \\
\hline Nine meter distance & $12.7 \pm 0.4 \mathrm{a}$ & $11.1 \pm 5.4 \mathrm{a}$ \\
\hline Twenty meter distance & $12.8 \pm 0.5 \mathrm{a}$ & $12.16 .0 \pm 6.0 \mathrm{a}$ \\
\hline
\end{tabular}

*Mean values with the same letter are not significantly different.

The growth parameters of teff varied significantly $(\mathrm{P}<0.01)$ at different distances from the
Eucalyptus woodlot. The highest plant height $(97.33 \pm 3.62)$ was recorded at twenty meter distance 
from the woodlot and the lowest was recorded at one meter distance $(72.53 \pm 0.82)$ from woodlot. Similarly for tiller number and spike length high at twenty meter distance and lower results were recorded at one meter distance.

\begin{tabular}{l} 
Table-4: Report table for the growth parameter of teff at different distance from the stand \\
$\qquad$\begin{tabular}{|l|l|l|l|}
\hline Distance from & Growth parameter of teff $($ Mean \pm SE) \\
\cline { 2 - 4 } Eamaldulensis woodlot & plant height $(\mathbf{c m})$ & spike length $(\mathbf{c m})$ & tiller no. \\
\hline One meter distance & $72.53 \pm 0.82^{\mathrm{b}}$ & $24.27 \pm 0.44^{\mathrm{b}}$ & $3.4 \pm 0.23^{\mathrm{b}}$ \\
\hline Three meter distance & $79.85 \pm 2.83^{\mathrm{b}}$ & $25.80 \pm 1.06^{\mathrm{b}}$ & $4.2 \pm 0.20^{\mathrm{b}}$ \\
\hline Six meter distance & $84.87 \pm 2.72^{\mathrm{ab}}$ & $29.53 \pm 2.13^{\mathrm{ab}}$ & $3.8 \pm 0.07^{\mathrm{b}}$ \\
\hline Nine meter distance & $84.60 \pm 3.47^{\mathrm{ab}}$ & $28.40 \pm 1.75^{\mathrm{ab}}$ & $3.8 \pm 0.20^{\mathrm{b}}$ \\
\hline Twenty meter distance & $97.33 \pm 3.62^{\mathrm{a}}$ & $34.27 \pm 1.52^{\mathrm{a}}$ & $5.3 \pm 0.13^{\mathrm{a}}$ \\
\hline
\end{tabular} \\
\hline
\end{tabular}

\section{DISCUSSION}

The effect of Eucalyptus woodlot on bulk density, soil moisture and pH

According to this study with increase the distance from the E. camaldulnsis woodlot to farmland soil bulk density is increase while soil moisture is decrease. This result is in line with Hailu et al. (2003), who reported that soil bulk density near Eucalyptus stand, was lower than that of the adjacent grazing land, attributed to the difference in SOC. In addition the soil bulk density under Eucalyptus was low and increased with distance from tree stand. The soil bulk density was negatively correlated with SOC, because it improves soil aggregation and soil porosity. Therefore, the difference in bulk density at the distances in this study could be attributed to the difference in SOC with distance from Eucalyptus woodlot. In addition, soil compaction in the cropland, which caused by continuous tillage by trampling and also oxidation of SOC indirectly (Yoshinori et al., 2009).

In the present study, the soil moisture content had increased with distance from wood-lot, which could be attributed to the high consumption of water by $E$. Camaldulensis tree in and closer to the wood-lot, whose influence decreases with distance from wood-lot and high accumulation of fiber roots of E. camaldulensis (Tilashwork, 2009). Eucalyptus has high water uptake potential and its roots grow up to six to nine meters, extracting water from a greater depth (Mekonnen, 2016). The high water need and its deep root systems enable Eucalyptus to compete successfully over other plants (Jagger and Pender, 2003). Eucalyptus consume high amount of water, which much affects the moisture content of the surrounding soil (Tegenu et al., 2008). Similarly, the moisture content of soil under E. saligna was significantly lower compared to soil under the farm land (Fikadu et. al., 2012). In contrast, Ambachew et. al., (2012) reported that the moisture content Eucalyptus species was not different from the other land uses like crop land. As shown the section 3.2 below the organic carbon is higher near to the woodlot than far distance in contrast to soil moisture which lowers near to the woodlot, it may be as result of higher fiber root concentration at 5 distances (Tilashwork, 2009).
The $\mathrm{pH}$ did not significantly vary $(\mathrm{p}>0.05)$ with distances from woodlot and soil depth that indicates soil reaction with the cropland is similar. This was in contrast to the claims that Eucalyptus has high acidifying effect on soil. Consistent to our findings, Juice (2016) showed that agricultural land and $E$. camaldulensis stand shad similar soil $\mathrm{pH}$ in the northern Ethiopia. In addition, the soil pH in Eucalyptus stands was similar to the soils in the adjacent agricultural land (Tegenu et al., 2008; Hailu, 2009). In contrast to the present study, the $\mathrm{pH}$ was lower in Eucalyptus stand and the closer distances than in the cropland (Telashwork, 2009).

\subsection{The effect of Eucalyptus woodlot on SOC}

The mean SOC decreased with increase in distance from Eucalyptus stand and it contributed by low litter fall with distance from wood-lot is increased (Yuri et al., 2002). In contrast, Duguma et al., (2010) reported that SOC was lowest for cereal farms and with relatively higher values in woodlot. Similar works found that SOC in Eucalyptus plantation stand was higher than agricultural land (Syad, 2006; Juice et al. 2016; Schulte, 1995). The low SOC in agricultural land than in Eucalyptus wood_lote is higher oxidation of SOC due to intensive cultivation (Dessie and Erkossa, 2011). Fernando et al. (2010) found that better SOC as result of high organic matter addition and low decomposition rate because of low nutrient concentrations those important for soil microbes. Hailu et al. (2003) showed that SOC concentrations did not differ among Eucalyptus plantation and agricultural land at two sites. However, the result of the present study showed a significantly high SOC value at one meter distance might be related to weeds and other herbaceous plants, which grow in the space between the edge of woodlot and the cropland, and their litter inputs. The SOC decreased with soil depth, and SOC was higher in the surface soil layer $(0-10 \mathrm{~cm})$, which is due to addition of litter on the surface.

\subsection{The effect of Eucalyptus woodlot on soil nutrients (TN, avail $P$ and avail $K$ ) \\ Different land use studies have compared the} soil nutrients between woodlot and croplands. Janice (2010) found no difference in soil TN between 
Eucalyptus stand and cropland in northern highlands of Ethiopia. Similarly, TN was not different between the soils of Eucalyptus plantations and adjacent agricultural lands in Ethiopia (Hailu et al., 2003). In contrast, the total $\mathrm{N}$ concentration was lower in the E. camaldulensis stand as compared to an open area in South Africa (Tererai et al. 2014) while TN in the soil was higher in Eucalyptus grandis stand than in the croplands in southwestern Ethiopia (Lemma et al., 2006). Differences in the results could be due to differences in soil type, climate and management of Eucalyptus as well as croplands.

The results of avail Pin the present study agrees with other studies (Tilashwork, 2009; Yoshinori et al. 2009; Muche et al., 2015). Yoshinori et al. 2009 showed that the available $\mathrm{P}$ concentration in the $E$. Camaldulensis stand was lower than other land uses like agricultural land. Available $\mathrm{P}$ was also low in plantation dominated by Eucalyptus than crop lands in (Muche et al., 2015). Tilashwork (2009) indicated that fine roots are responsible for nutrient absorption and Eucalyptus stand can influences ten-meters away from the stand. The declining trend in the present study was up to six-meters and it is the influence of much accumulated E.camaldulensis fine roots.

Low concentration of avail $\mathrm{K}$ was found in Eucalyptus stand when compared to croplands (Syad, 2006). In contrast, Hailu, et al. (2003) has found high avail $\mathrm{K}$ concentration in the soils of Eucalyptus as compared to adjacent cropland. Similarly, Eucalyptus plantation forest had higher avail $\mathrm{K}$ concentration than cropland (Muche et al., 2015). On surface soil layer, avail $\mathrm{K}$ concentration was higher than sub-surface layer and similar results were found in other studies (Syad, 2006).

\section{The effect of $E$. camaldulensis woodlot ongrowth and yield of teff planted on the adjacent cropland}

Comparable to the present study, Tilashwork (2009) found that the yield, biomass and height of maize increased with distance from the Eucalyptus woodlot. She agreed that the loss of crop yield is the competition of soil nutrients and light by $E$. camaldulensis to crops (Tilashwork et al., 2013). Similarly, Alebachew et al. (2015) showed that the height, biomass and grain yield of maize decreased with decrease distance from the adjacent Eucalyptus stands. Mugunga et al. (2017) recognized that the reduction in maize yield planted adjacent to E. saligna woodlot to the soil moisture as the soil moisture near the woodlots was lower compared to the values in open areas. In his study, the amount of the solar radiation near the woodlots was reduced by $68 \%$ compared to the open areas. The trend in soil nutrients with distance from the Eucalyptus woodlot could be related to the reduction in teff growth parameters (e.g. Figure $3 \& 4$ ). Some studies have describes the loss of crop yield at closer distances from Eucalyptus stands to the competition of
Eucalyptus for soil nutrients with crops (Tilashwork et al., 2013, Mugunga et al., 2017). Moreover, Florentine and Fox (2003) showed that certain phenolic acids and volatile oils in Eucalyptus victrix seedlings functioned as allelopathic agents on a grass species in Australia. Lisanework (1993) studied the allelophatic effect of Eucalyptus leaves and he showed that aqueous extract of the leaves of E. camaldulensis and E. glubulus influence teff growth than other tree species. Thus, Eucalyptus could influence crops growing either under or adjacent to it due to the production of allelopathic chemicals. These factors could influence the yield and other parameters of teff in the present study.

\section{CONCLUSIONS AND RECOMMENDATION}

According to this study, soil properties and teff growth parameters on the cropland varied with distance from the adjacent E. Camaldulensis woodlot. Soil bulk density, moisture content, SOC, avail $\mathrm{P}$ and avail K showed a decreasing trend up to six and nine meter distance from the woodlot and increasing trend thereafter. The yield and height of teff was significantly reduced with distance from Eucalyptus woodlot. The yield and height of teff was strongly affected up to six meter distance from the woodlot. The decline in yield of the teff crop in this study was attributed by the decline in the soil moisture and soil nutrient. In the studied agro ecosystem and other similar agro ecosystems, where Eucalyptus woodlots are an integral part of the agricultural landscape, we recommend crop cultivation at distances six meter or greater away from the woodlot to minimize effects of $E$. camaldulensis associated with crop.

\section{ACKNOWLEDGEMENTS}

This research was funded by the Southern Agricultural Research Institute. We are grateful to the Southern Agriculture and Natural Resource Soil Testing Laboratory for soil analysis.

\section{Funding}

This work is funded by southern agricultural research institute (SARI) only for field work.

\section{Conflict interst}

The authors declare that they have no conflict of interest.

\section{REFERENCES}

- Alebachew, M., Dar, B., Dar, B., \& Dar, B. (2015). Investigation of the Effects of Eucalyptus camaldulensis on Performance of Neighbouring Crop Productivity in Western Amhara, Ethiopia. Open Access Library Journal, 2(03), 1.

- Demessie, A., Singh, B. R., Lal, R., \& Børresen, T. (2012). Effects of eucalyptus and coniferous plantations on soil properties in Gambo District, southern Ethiopia. Acta Agriculturae Scandinavica, Section B-Soil \& Plant Science, 62(5), 455-466. 
- Anderson, J. M., \& Ingram, J. S. I. (1993). Tropical soil biology and fertility: A handbook of methods. eds (No. 631.46 AND. CIMMYT.).

- $\quad$ AWETO*, A. O., \& Moleele, N. M. (2005). Impact of Eucalyptus camaldulensis plantation on an alluvial soil in south eastern Botswana. International journal of environmental studies, 62(2), 163-170.

- Davidson, J. (1993, October). Ecological aspects of Eucalyptus plantations. In Proceedings of the regional expert consultation on Eucalyptus (Vol. 1, pp. 35-72). RAPA/FAO, Bangkok, Thailand.

- Lemenih, M., \& Kassa, H. (2014). Re-greening Ethiopia: history, challenges and lessons. Forests, 5(8), 1896-1909.

- Dessie, G. (2011). Eucalyptus in East Africa: socio-economic and environmental issues (No. H043946). International Water Management Institute.

- Duguma, L. A., Hager, H. E. R. B. E. R. T., \& Sieghardt, M. O. N. I. K. A. (2010). Effects of land use types on soil chemicalproperties in smallholder farmers of central highland Ethiopia. Ekológia (Bratislava... Ekológia (Bratislava), 29(1), 1-14.

- El-Khawas, S. A., \& Shehata, M. M. (2005). The allelopathic potentialities of Acacia nilotica and Eucalyptus rostrata on monocot (Zea mays L.) and dicot (Phaseolus vulgaris L.) plants. Biotechnology, 4(1), 23-34.

- Eyasu, E. (2016). Soil of Ethiopian high land geomorphology and properties. CASCAP project ALTERA, wageningen University and research center (Wageningen UR) Netherland, 358pp

- $\quad$ Leite, F. P., Silva, I. R., Novais, R. F., Barros, N. F. D., \& Neves, J. C. L. (2010). Alterations of soil chemical properties by eucalyptus cultivation in five regions in the Rio Doce Valley. Revista Brasileira de Ciência do Solo, 34(3), 821-831.

- Getachew, F., Abdulkadir, A., Lemenih, M., \& Fetene, A. (2012). Effects of different land uses on soil physical and chemical properties in Wondo Genet area, Ethiopia. New York Science Journal, 5(11), 110-118.

- Fox, J. (2003). Allelopathic effects of Eucalyptus victrix L. on Eucalyptus species and grasses.

- Forrester, D. I., Bauhus, J., Cowie, A. L., \& Vanclay, J. K. (2006). Mixed-species plantations of Eucalyptus with nitrogen-fixing trees: a review. Forest Ecology and Management, 233(23), 211-230.

- $\quad$ Friis, I., Myrtaceae. S., Edward, M. Tads, I. Edberg eds. (1995). Flora of Ethiopia and Eritrea,: Canellaceae to Euphorbiaceae. The National Herbarium, Addis Ababa University, Addis Ababa, Ethiopia.

- Haile, G., Lemenhi, M., Itanna, F., \& Senbeta, F. (2014). Impacts of land uses changes on soil fertility, carbon and nitrogen stock under smallholder farmers in central highlands of
Ethiopia: Implication for sustainable agricultural landscape management around Butajira area. $N Y$ Sci J, 7(2), 27-44.

- Hailu, Z., Sieghardt, M., Schume, H., Ottner, F., Glatzel, G., Assefa, B., \& Hailu, T. T. (2003). Impact of Eucalyptus globulus and Eucalyptus camaldulensis small scale plantations on chemical and physical soil properties and on soil hydrological parameter in the highland of Ethiopia: A comparison with other land-use systems. Final Project Report, 183.

- Jackson, M. L. (1958). Soil chemical analysis. Prentice Hall, Inc., New Jersey, USA.

- Jagger, P., \& Pender, J. (2003). The role of trees for sustainable management of less-favored lands: the case of eucalyptus in Ethiopia. Forest Policy and Economics, 5(1), 83-95.

- Janice, L., Travis, R., Alemayehu, W., Cathy, C. O., \& Atalel, W. (2016). Effects of exotic Eucalyptus spp. plantations on soil properties in and around sacred natural sites in the northern Ethiopian Highlands. Agriculture and Food, 1(2); 175-193

- Ketema, S. (1997). Teff, Eragrostistef (Zucc.) trotter. Rome, Italy: Institute of Plant Genetics and Crop Plant Research, Gatersleben/International Plant Genetic Resources Institute. pp. 52

- Khan, M.A., Khitran, T.A., Baloch, M.S., \& Suiemani, M.Z. (1999). Allelopathic effect of eucalyptus on soil characteristics and growth of maize. Pakistan Journal of Biology Science, 2(1), 390-393.

- Kwakwa, P., \&Wiafe, E. (2014). I Use Firewood but I Do Not Grow Trees: An Analysis of Tree Planting Exercise among Rural Households in Ghana. Asian Bulletin of Energy Economics and Technology, 1(1), 7-12.

- Laclau, J. P., Ranger, J., Goncalves, J. L. D., Maquere, V., Krusche, A. V., M'Bou, A. T., Nouvellon, Y., Saint-Andre, L., Bouillet, J. P., Piccolo, M. D., and Deleporte, P. (2010). Biogeochemical cycles of nutrients in tropical Eucalyptus plantations: Main features shown by intensive monitoring in Congo and Brazil, Forest Ecology Management, 259, 1771-1785.

- Leicach, S.R., Guarnaschelli, A.B., Garau, A.M., Chludil, H.D., Grass, M.Y., \& Fernandez, P.C. (2012). Chemical Defenses in Eucalyptus Species: A Sustainable Strategy Based on Antique Knowledge to Diminish Agrochemical Dependency. INTECH Open Access Publisher.

- Lemenih, M. (2010). Growing eucalypts by smallholder farmers in Ethiopia. In Proceedings of the Conference on Eucalyptus Species Management, History, Status and Trends in Ethiopia, Addis Ababa, Ethiopia, 1; 517.

- Lisanework, N., \& Michelsen, A. (1993). Allelopathy in agroforestry systems: the effects of leaf extracts ofCupressus lusitanica and 
threeEucalyptus spp. on four Ethiopian crops. Agroforestry systems, 21(1), 63-74.

- Mehlich, A. (1984). Mehlich-3 soil test extract ant: A modification of Mehlich2 extractant. Communications in Soil Science \& Plant Analysis, 15(12);1409-1416.

- Mekonnen, D. (2016). The Eucalyptus Dilemma: The Pursuit for Socio-economic Benefit versus Environmental Impacts of Eucalyptus in Ethiopia. Journal of Natural Sciences Research, www.iiste.org ISSN 2224-3186 (Paper), ISSN 2225-0921 (Online), 6, (19),127-137.

- Michelsen, A., Lisanework, N., \& Friis, I.B. (1993). Impacts of tree plantations in the Ethiopian highland on soil fertility shoot and root growth, nutrient utilisation and mycorrhizal colonization. Forest ecology and management, 61, 299-324.

- Muche, M., Kokeb, A., Molla, E. (2015). Assessing the Physicochemical Properties of Soil under Different Land Use Types. Journal of Enviroment and Analatical Toxicolology 5: 309. doi:10.4172/2161-0525.1000309

- Mugungaa, C.P., Giller, K.E., Mohren, G.M.J. (2017). Tree-crop interactions in maize-eucalypt woodlot systems in southern Rwanda. European Journal of Agronomy, 86, 78-86

- Olsen, Sterling, R. (1954). Estimation of available phosphorus in soils by extraction with sodium bicarbonate. United States Department of Agriculture; Washington.

- Place, F., Ajayi, O. C., Torquebiau, E., Detlefse N, G., Gauthier, M., \& Buttoud, G. (2012). Improved Policies for Facilitating Adoption of Agroforestry. In Agroforestry for Biodiversity and Ecosystem Services-Science and Practice (pp. 113-128). INTECH.

- Pohjonen, V., \& Pukkala, T. (1991). Which eucalypt grows best in Ethiopian highlands? Biomass and Bioenergy, 1(4), 193-198.

- Sarkar U.K., Saha B.J., Goswami C. and Chowdhury M.A.H. (2010). Leaf litter amendment in forest soil and their effect on the yield quality of red amaranth. Journal of the Bangladesh Agricultural University, 8(2), 221-226.
- Schulte, E.E. (1995). Recommended soil organic matter tests. Recommended Soil Testing Procedures for the North Eastern USA. Northeastern Regional Publication, (493), 52-60.

- Selamyihun, K., Stroosnider, L. (2004). Soil erosion and seasonal water use in Eucalyptus globules based rotational agroforestry system on Ethiopian highland vertisols. Wageningen Univrsity publish as Tropical Resource Manegement Papers, No. 52, ISBN 90-6754-733-6

- Syad Baber, Ahmad, M. F., \& Bhatti, A. (2006). The effect of Eucalypts camaldulensis on soil properties and fertility. Journal of Agricultural and Biological Science, 1(3), 47-50.

- Tegenu A. Engda Habitamu T. Kassahun, Amy S., Collick, Teenage Disso, Bin yam B. Ashore, Zealand K. Bessemer, Assefa Deere, Dewitt Solomon and Tambo S. Stenches, (2009). Soil Properties and Fertility Status Dynamics of North Western Ethiopia as Influenced by Land Use Changes: Case of Diane Watershed. https://www.researchgate.net/publication/25899343 0 Research Gate. Journal, volume and pages.

- Tererai, F., Gartner, M., Jacobs, S.M., \& Richardson, D.M. (2015). Eucalyptus Camaldulensis Invasion in Riparian Zones Reveals Few Significant Effects on Soil Physico-Chemical Properties. River Research and Applications, 31(5), 590-601.

- Tilashwork, C., Collick, A.S., Adgo, E., Lehmann, C.J., \& Steenhuis, T.S. (2013). Eco-hydrological impacts of Eucalyptus in the semi humid Ethiopian Highlands: the Lake Tana Plain. Journal of Hydrology and Hydromechanics, 61(1); 21-29.

- Yoshinori W., Tsugiyuki M. ,Oluwarotimi O. F., Adeniyi A., Peter K. O., \& Toshiyuki W. (2009). Eucalyptus camaldulensis and Pinus caribaea growth in relation to soil physico-chemical properties in plantation forests in Northern Nigeria, Soil Science and Plant Nutrition, 55, 132-141, DOI: 10.1111/j.1747-0765.2008.00340.x

- Yuri. L. Zinn, Dimas. V.S., Resk, Jose, E. Da Silva. (2002). Soli organic carbon as affected by afforestation by eucalyptus spp. and pinus in cerrado region of Brazil. Journal of forest ecology and management, 166, 285-294.

Cite This Article: Begashaw Mitiku, Bekele Lemma, Fantaw Yimer (2022). Eucalyptus camaldulensis Woodlot Influences Soil Properties and Teff Yield on the Adjacent Croplands in Guraghe Zone, Central Ethiopia. EAS J Biotechnol Genet, 4(1), 1-10. 